\title{
Studying the mutagenic activity of drinking water and soil samples selected from Kentau and adjacent territories
}

\author{
Oksana Cherednichenko ${ }^{1, *}$, Serikbay Nuraliev ${ }^{1}$, Galym Berkinbaev ${ }^{2}$, Natalia Yakovleva $^{2}$, \\ Yerlan Sadvakasov ${ }^{2}$, Anastassiya Pilugina ${ }^{1}$ and Gulnara Baigushikova ${ }^{1}$ \\ ${ }^{1}$ Institute of Genetics and Physiology, Almaty, Kazakhstan \\ ${ }^{2}$ ECOSERVICE-S LLP, Almaty, Kazakhstan
}

\begin{abstract}
In the course of carrying out a comprehensive assessment of the state of the environment and health of the population of the city of Kentau and adjacent territories, a study of the mutagenic activity of drinking water and soil samples taken in the territory of Kentau and adjacent settlements, the background territory and the comparison territory was carried out. In the course of the study, it was revealed that individual samples of drinking water and water extracts of soils cause a significant increase in the frequency of chromosomal abnormalities in the cultures of human peripheral blood lymphocytes and in the Allium-test. Analysis of the total mutagenic activity of the samples under study indicates the absence of a fundamentally contaminated and/or clean territory in the studied region, which indicates their general contamination with a tendency to increase contamination in some places.
\end{abstract}

\section{Introduction}

In some regions of Kazakhstan, due to human production and economic activities, as well as the influence of socio-economic factors, changes in the environment have acquired the character of an ecological catastrophe. Such ecologically unfavorable regions, first of all, include East Kazakhstan, Semipalatinsk and Aral.

The city of Kentau and the adjacent settlements are located in the Turkestan region at a distance of about $30 \mathrm{~km}$. from the city of Turkestan at the foot of the Karatau ridge. Kentau was established in August 1955 to develope the Achisai polymetallic deposit. Development of a deposit of lead-zinc and barite ores determined the specifics of the socio-economic development of the city. In 1994, ore mining at the deposit was stopped. The consequences of mining and the termination of the activities of enterprises caused the main environmental problems of the region - pollution of the environment with heavy metals caused by dusting of the tailing dump, and change in the geological environment. On the other hand, the city of Kentau and adjacent settlements are located in close proximity to the ecologically unfavorable territories of the Aral region. So, according to the Law of the Republic of Kazakhstan "On social protection of citizens affected by the environmental disaster in the

*Corresponding author: cherogen70@,mail.ru 
Aral region", the territory of the Suzak district of the Turkestan region and the city of Turkestan, but not Kentau belong to the zone of the ecological pre-crisis state.

Over the past 10-15 years, various problems of the environmental situation that occured in the Aral region in connection with the "Aral catastrophe" have been actively studied. Analysis of soil contamination, irrigation tracts of the Aral Sea region, revealed not only the presence, but also an increased content of a number of chemical toxic elements, including heavy metals and pesticides belonging to known mutagenic factors [1]. It is believed that even minor pollution of the territories of residence can have adverse effects on public health. Also, one of the reasons for the deterioration of the health of people in the Aral region is highly mineralized water sources.

In accordance with article 175 of the Environmental Code of the Republic of Kazakhstan, the assessment of the ecological situation of the territories is carried out on the basis of the main and additional types of criteria [2]. The criteria for assessing the ecological situation of the territories used in the Republic of Kazakhstan until 2015 included the total mutagenic effects in the samples of air, water and other environmental components. Excess of the level of total mutagenic effects in the samples of environmental objects in the study area in comparison with the background 3 times or more indicated an ecological disaster zone, if exceeded up to 3 times - about an ecological emergency zone [2].

There are no indicators of the total mutagenicity of environmental objects in the current version of the Criteria for Assessing the Ecological Situation of Territories [3], and therefore, we believe, the results of comprehensive studies of the state of the environment in the study area may not have an important information.

The purpose of this study was to assess the mutagenic activity of drinking water and soil samples taken on the territory of Kentau and adjacent settlements (the villages of Achisay, Bayaldyr, Burgem, Kantagi, Karnak, Kushata, Shashtobe), the reference area and the comparison territory. The study was carried out within the project "Comprehensive assessment of the state of the environment and health of the population of the city of Kentau and adjacent settlements" (the Customer - akimat of Kentau).

The territory of Lenger was taken as the reference area, which has similar socioeconomic living conditions, a favorable ecological situation, and there are no factors affecting the quality of the environment.

The urban area (city of Turkestan) and the rural area (the village of Orangai), which are closest to the study zone, are taken as the comparison area. They belong to the zone of the ecological pre-crisis state in accordance with the Law of the Republic of Kazakhstan dated June 30, 1992 No. 1468-XII "On social protection of citizens affected by the environmental disaster in the Aral region".

Currently, for testing chemicals and component compositions for mutagenicity, a system of short-term screening tests (CST) is widely used, which is based on modern data on the mechanisms of chemical mutagenesis.

The mutagenic activity of drinking water and soil samples from settlements of Kentau district, the reference territory and the comparison territory was studied using two test systems - the study of microderms in the Allium-test (proved to be a suitable model for studying the ecological and cytogenotoxic potential of pollutants and was adopted by the International Plant Bioanalysis Program (IPPB) for monitoring or testing environmental pollutants [5-7] and was recommended by experts of the World Health Organization as a standard in cytogenetic monitoring of the environment) and the analysis of chromosomal abnormalities in cultures of human lymphocytes (is one of the essential test systems for evaluating the effect of mutagenic environmental factors). 


\section{Materials and methods}

The objects of research were water (17 pieces) and soil (16 pieces) samples collected in these territories. In the city of Kentau, 5 water samples and 4 collected soil samples were taken, in the vicinity of Kentau - 7 water samples and 7 collected soil samples ( 7 villages), in Lenger - 2 water samples and 2 collected soil samples, in the city of Turkestan - 2 water samples and 2 collected soil samples, in the village of Orangai 1 water sample and 1 collected soil sample.

Water samples were taken from water supply sources and from the distribution network. In order to study the mutagenic activity of the soil, in order to increase the representativeness, prefabricated samples were formed, consisting of soil samples taken by the "envelope method" in different areas of the studied settlement. Drinking water quality assessment was carried out in accordance with the current legislation [8].

Testing for mutagenic activity was carried out for each sample separately, then the results were summarized by localities. For internal control, we used sterile distilled water, for external control - clean universal soil and soil from the National Park of the Republic of Kazakhstan Altyn-Emel (Basshi settlement).

To prepare water extracts of soils, $150 \mathrm{ml}$ of distilled water were added to soil samples weighing $30 \mathrm{~g}$. The soil and water were mixed for $3 \mathrm{~min}$ on a mixer and left for $5 \mathrm{~min}$ to settle (GOST 26423-85 Soil. Methods for determining the specific electrical conductivity, $\mathrm{pH}$, and dense residue of the water extract). The aqueous fraction was collected, centrifuged and used for testing.

The prepared aqueous soil extracts and drinking water samples were sterilized and used for further studies using human lymphocyte cultures. The Allium-test method was used to study native samples.

To study cytogenetic disorders using the Allium cepa test object, onion seeds were germinated in Petri dishes in a test sample at a temperature of $22-24^{\circ} \mathrm{C}$ (for $48-72$ hours). When the roots reached 2-3 cm, the tip was cut off with a length of $1-2 \mathrm{~cm}$. It was placed in a fixative (ethanol / glacial acetic acid - 3/1) for 4-24 hours; hydrolyzed in $1 \mathrm{~N} \mathrm{HCl}$ at $60^{\circ} \mathrm{C}$ for 8-10 min., washed in distilled water and placed in a vial with orsein solution in a boiling bath for 6-12 minutes. The dark-colored root tip was cut off and transferred to a drop of $45 \%$ acetic acid on a glass slide. The material was covered with a cover slip and crushed until the cells were distributed into a monolayer. Then microscopic analysis and assessment of the selected cytogenetic parameters were performed.

Cell damage was assessed under a microscope using the ana-telophase method and micronucleus analysis [2-4]. In the Ana-telophase method, the frequency of damage was studied by taking into account the sum of chromosomal aberrations, lagging chromosomes and bridges at the anaphase and telophase stages to the total sum of ana-telophases on the preparation ( $\Sigma$ otc. $+\mathrm{CA}+$ bridge, $\%$ ). The micronucleus test serves to determine the frequency of micronuclei in interphase cells, the account of micronuclei in interphase cells is carried out to the total amount of analyzed interphases on the preparation ( $\mathrm{Mw}, \%)$. The micronucleus test at the interphase stage enables to expand the range of studied cells, which makes the method even more rapid and economical. In all variants, the mitotic index $\mathrm{MI}=$ $(\Sigma(\mathrm{P}+\mathrm{M}+\mathrm{A}+\mathrm{T}) / \mathrm{N}) \times 100 \%$ was also taken into account, where, $(\mathrm{P}, \mathrm{M}, \mathrm{A}, \mathrm{T})$ the sum of cells at the stages of cell division (prophase, metaphase, anaphase, telophase, respectively), $\mathrm{N}$ is the total number of analyzed cells [11].

For analyzing the mutagenic activity of water samples and water extracts of soils, $10 \%$ of each (pre-sterilized) sample (from the amount of cultivation medium) was added to the lymphocyte cultures. Each sample was examined in lymphocyte cultures using the blood of two healthy donors. 
Cultivation of lymphocytes and preparation of preparations was carried out according to the following procedure: to $0.5 \mathrm{ml}$ of peripheral blood was added to $4.5 \mathrm{ml}$ of cultivation medium, consisting of $80 \%$ RPMI-1640 medium with glutamine $(2 \mathrm{mM}), 20 \%$ cattle serum, penicillin $100 \mathrm{U} / \mathrm{ml}$, streptomycin 100 units $/ \mathrm{ml}$. Lymphocyte division was stimulated by $2 \%$ PHA. The cells were incubated at $37^{\circ} \mathrm{C}$ for 48 hours. For the accumulation of metaphase plates, colchicine at a final concentration of $0.8 \mu \mathrm{g} / \mathrm{ml}$ was introduced into the culture medium 2 hours before fixation. To obtain cytological preparations, cells were hypotonicated with $0.075 \mathrm{M} \mathrm{KCl}$ at $37^{\circ} \mathrm{C}$ for 15 minutes, fixed with a mixture of methyl alcohol / glacial acetic acid (3/1) and stained with $4 \%$ Giemsa dye solution. When analyzing the metaphase plates, the number of cells with aberrations was determined, as well as the number and type of aberrations per 100 analyzed metaphases [12].

The chromosome preparations were stained with a 4\% Giemsa dye solution for $5 \mathrm{~min}$. Cytogenetic analysis was carried out on encrypted preparations by the method of "blind control" under a light microscope from Zeiss at a magnification of $16 \times 100$ by visual karyotyping. When analyzing metaphase plates, the number of cells with aberrations was determined, as well as the number and type of aberrations per 100 analyzed metaphases.

When analyzing the data obtained, we used standard methods of statistical analysis.

\section{Results and discussion}

Chemical analysis of drinking water did not reveal any deviations from the current hygienic standards for the content of harmful substances. A comprehensive assessment of the contamination of soil samples taken on the territory of the studied settlements and subjected to further assessment of the total mutagenic activity was carried out by calculating the total pollution index $\mathrm{Zc}[9,10]$. Calculation of $\mathrm{Zc}$ included information on the content of the following elements: $\mathrm{P}, \mathrm{Pb}, \mathrm{Ba}, \mathrm{Mo}, \mathrm{Cu}, \mathrm{Zn}$, As. The results of calculating $\mathrm{Zc}$ in soil samples are presented in Table 1.

Table 1. - Contamination levels of soil samples from the territory of Kentau and adjacent settlements, reference and comparison territories, according in terms of $\mathrm{Zc}$

\begin{tabular}{|c|c|c|c|}
\hline \multirow{2}{*}{ Locality } & \multicolumn{3}{|c|}{ Value Zc } \\
\cline { 2 - 4 } & Average & Min & Max \\
\hline Kentau city & 19.84 & 13.03 & 38.21 \\
\hline Neighborhood Kentau & 17.70 & 2.77 & 17.61 \\
\hline Lenger city (background area) & 1.48 & 1.34 & 1.61 \\
\hline $\begin{array}{c}\text { Turkestan and Orangay village } \\
\text { (comparison territory) }\end{array}$ & 2.75 & 0.12 & 5.91 \\
\hline
\end{tabular}

Pollution is considered permissible at $\mathrm{Zc}<16$, moderately dangerous - at 16-32, dangerous - at 32-128, extremely dangerous - at $\mathrm{Zc}>128$ [9, 10]. According to the information provided, on the territory of Kentau and adjacent settlements, soil contamination is moderately hazardous, in the reference and comparison areas is permissive.

The results of water samples in the Allium-test from the survey region are presented in Table 2. According to the data obtained, the mitotic index is halved in almost all samples, without fundamental differences between them. This indicates the toxic effect of the studied samples on the Allium cepa system.

According to the Allium test, Kentau and its surroundings and Lenger have the highest mutagenicity of water samples, exceeding the control level by 7-10 times, while it significantly differs $(\mathrm{p} \leq 0.01)$ from the results of testing water samples from Turkestan and Orangai village. 
Table 2. Study of mutagenic activity of drinking water samples from the settlements of Kentau city using the Allium-test

\begin{tabular}{|c|c|c|c|c|c|}
\hline Locality & Total cells & Interphase, $\%$ & Metaphase, $\%$ & Anaphase, $\%$ & MI \\
\hline Kentau city & 5040 & $0.78 \pm 0.1$ & $3.29 \pm 0.2$ & $2.42 \pm 0.2$ & $10.2 \pm 0.4$ \\
\hline Neighborhood Kentau & 8048 & $0.63 \pm 0.08$ & $2.88 \pm 0.1$ & $4.44 \pm 0.2$ & $9.29 \pm 0.3$ \\
\hline Lenger city & 2018 & $0.59 \pm 0.1$ & $1.92 \pm 0.3$ & $1.37 \pm 0.2$ & $8.61 \pm 0.6$ \\
\hline Orangay village & 942 & $0.12 \pm 0.1$ & $0.1 \pm 0.1$ & 0 & $11.46 \pm 1.03$ \\
\hline Turkestan city & 2004 & $0.11 \pm 0.07$ & 0 & 0 & $10.52 \pm 0.6$ \\
\hline $\mathrm{dH}_{2} \mathrm{O}$ & 1522 & $0.08 \pm 0.07$ & 0 & $0.3 \pm 0.1$ & $19.00 \pm 1.0$ \\
\hline
\end{tabular}

In Orangai and Turkestan, the frequency of micronuclei does not fundamentally differ from the control level (dist. water). The results of water samples from Kentau taken at the treatment plant are interesting - the mutagenicity of water at the new treatment plant is at the control level, and at the old one it exceeds it by more than 5 times

The results of the cytogenetic analysis of human peripheral blood lymphocytes on the study of the mutagenic activity of drinking water samples from populated areas taken from the district of Kentau are presented in Table 3.

Table 3. Study of mutagenic activity of drinking water samples on cultures of human lymphocytes

\begin{tabular}{|c|c|c|c|c|c|c|}
\hline \multirow{2}{*}{ Locality } & \multirow{2}{*}{$\begin{array}{c}\text { Number } \\
\text { of cells } \\
\text { analyzed }\end{array}$} & \multirow{2}{*}{$\begin{array}{c}\text { Total } \\
\text { aberrations } \\
(\%)\end{array}$} & \multicolumn{3}{|c|}{ Chromosomal type (\%) } & \multirow{2}{*}{$\begin{array}{l}\text { Chromatid } \\
\text { type (\%) }\end{array}$} \\
\hline & & & Total & $\begin{array}{l}\text { Dicentrics, } \\
\text { rings, } \\
\text { translocations }\end{array}$ & $\begin{array}{l}\text { Breaks, } \\
\text { fragm. }\end{array}$ & \\
\hline Kentau city & 1020 & $3.6 \pm 0.5$ & $1.36 \pm 0.3$ & $0.49 \pm 0.2$ & $0.87 \pm 0.2$ & $2.28 \pm 0.4$ \\
\hline Neighborhood Kentau & 1400 & $3.28 \pm 0.4$ & $1.5 \pm 0.3$ & $0.42 \pm 0.1$ & $1.07 \pm 0.2$ & $1.78 \pm 0.3$ \\
\hline Lenger city & 320 & $2.17 \pm 0.8$ & $1 \pm 0.5$ & $0.5 \pm 0.3$ & $0.5 \pm 0.3$ & $1.16 \pm 0.5$ \\
\hline Orangay village & 200 & $2 \pm 0.9$ & 0 & 0 & & $2 \pm 0.9$ \\
\hline Turkestan city & 400 & $2.5 \pm 0.7$ & $0.75 \pm 0.4$ & 0 & $0.75 \pm 0.4$ & $1.75 \pm 0.6$ \\
\hline Spontaneous level & 350 & $0.57 \pm 0.4$ & 0 & 0 & & $0.57 \pm 0.4$ \\
\hline $\mathrm{dH}_{2} \mathrm{O}$ (control) & 300 & $1 \pm 0.5$ & $0.33 \pm 0.3$ & 0 & $0.33 \pm 0.3$ & $0.67 \pm 0.4$ \\
\hline
\end{tabular}

The spectrum of recorded aberrations was quite wide and included chromosomal and chromatid aberrations. Chromosomal aberrations were represented by double breaks and fragments, centric and acentric rings, dicentrics and translocations, chromatid type - single breaks, fragments and exchanges.

Based on the data obtained in the test system - human lymphocyte culture, the samples from Kentau and its environs (highlighted in red) have the highest frequency of cytogenetic damages (4-5 times higher than control). Moreover, two of these samples from old treatment plant of Kentau have the highest mutagenicity in the Allium-test; 2-2.5-fold increase is observed when testing samples from Lenger, Turkestan and Orangai village. Similar results were recorded in the analysis of chromosomal aberrations in cultures of human lymphocytes and in the Allium-test at different stages of the cell cycle.

Study water extracts of soils by the Allium-test method (Table 4) reveals that the mitotic index is practically at the control level with a slight tendency to decrease in all samples.

Cytogenetic analysis revealed that the samples from Lenger and Turkestan have the highest frequency of micronuclei in interphase cells (2-2.3 times higher than control). Analysis of water extracts of soils from other settlements did not reveal a significant excess of the frequency of micronuclei in interphase cells in comparison with the control. In analyzing of chromosomal aberrations at different stages of the cell cycle, the samples from Lenger, Turkestan and Orangai village have a predominant excess of mutagenic activity compared with control. 
Table 4. Allium-test Study of the mutagenic activity of water extracts of soils of the settlements, taken from the region of Kentau using the Allium-test

\begin{tabular}{|c|c|c|c|c|c|}
\hline Locality & $\begin{array}{l}\text { Total } \\
\text { cells }\end{array}$ & Interphase, $\%$ & Metaphase, $\%$ & Anaphase, $\%$ & MI \\
\hline Kentau city & 4030 & $0.31 \pm 0.08$ & $6.11 \pm 0.3$ & $1.96 \pm 0.2$ & $10.71 \pm 0.4$ \\
\hline Neighborhood Kentau & 7028 & $0.28 \pm 0.06$ & $6.11 \pm 0.2$ & $0.97 \pm 0.1$ & $8.60 \pm 0.3$ \\
\hline Lenger city & 2014 & $0.62 \pm 0.1$ & $1.85 \pm 0.3$ & $2.82 \pm 0.3$ & $10.67 \pm 0.6$ \\
\hline Orangay village & 1005 & $0.33 \pm 0.1$ & $9.5 \pm 0.9$ & 0 & $8.85 \pm 0.8$ \\
\hline Turkestan city & 2019 & $0.54 \pm 0.1$ & $9.84 \pm 0.6$ & $5.0 \pm 0.4$ & $9.40 \pm 0.6$ \\
\hline Clean, versatile soil (control) & 1830 & $0.27 \pm 0.1$ & $1.54 \pm 0.2$ & 0 & $11.00 \pm 0.7$ \\
\hline
\end{tabular}

Cytogenetic analysis revealed the highest frequency of micronuclei in interphase cells (2-2.3 times higher than control) in the samples from Lenger and Turkestan. The water extracts of soils from other settlements did not have a significant excess of the frequency of micronuclei in interphase cells in comparison with the control. It was shown a predominant excess of mutagenic activity in samples from Lenger, Turkestan and Orangai village compared with control in analyzing of chromosomal aberrations at different stages of the cell cycle.

The results of the cytogenetic analysis of human peripheral blood lymphocytes on the study of the mutagenic activity of samples of water extracts from soils of the settlements of Kentau are presented in Table 5.

Table 5. Study of the mutagenic activity of water extracts of soil samples of Kentau using cultures of human lymphocytes

\begin{tabular}{|c|c|c|c|c|c|c|}
\hline \multirow[t]{2}{*}{ Locality } & \multirow{2}{*}{$\begin{array}{l}\text { Number } \\
\text { of cells } \\
\text { analyzed }\end{array}$} & \multirow{2}{*}{$\begin{array}{c}\text { Total } \\
\text { aberrations } \\
(\%)\end{array}$} & \multicolumn{3}{|c|}{ Chromosomal type $(\%)$} & \multirow{2}{*}{$\begin{array}{c}\begin{array}{c}\text { Chromatid } \\
\text { type (\%) }\end{array} \\
\text { Total }\end{array}$} \\
\hline & & & Total & $\begin{array}{l}\text { Dicentrics, } \\
\text { rings, } \\
\text { translocations }\end{array}$ & $\begin{array}{l}\text { Breaks, } \\
\text { fragm. }\end{array}$ & \\
\hline Neighborhood Kentau & 800 & $3.3 \pm 0.6$ & $1.0 \pm 0.3$ & $0.2 \pm 0.1$ & $0.8 \pm 0.3$ & $2.3 \pm 0.5$ \\
\hline Lenger city & 1430 & $3.9 \pm 0.5$ & $1.5 \pm 0.3$ & $0.5 \pm 0.1$ & $1.0 \pm 0.2$ & $2.3 \pm 0.3$ \\
\hline Orangay village & 400 & $5.0 \pm 1.0$ & $1.2 \pm 0.5$ & $0.7 \pm 0.4$ & $0.5 \pm 0.3$ & $3.7 \pm 0.9$ \\
\hline Turkestan city & 400 & $3.7 \pm 0.9$ & $1.7 \pm 0.6$ & $1.2 \pm 0.5$ & $0.5 \pm 0.3$ & $2.0 \pm 0.7$ \\
\hline Option & 400 & $5.5 \pm 1.1$ & $3.2 \pm 0.8$ & $1.2 \pm 0.5$ & $2.0 \pm 0.7$ & $2.5 \pm 0.7$ \\
\hline Spontaneous level & 350 & $0.5 \pm 0.3$ & 0 & 0 & $0.5 \pm 0.3$ & $0.5 \pm 0.3$ \\
\hline Basshi village & 300 & $3.3 \pm 1.0$ & $2.7 \pm 0.9$ & $0.7 \pm 0.4$ & $2 \pm 0.8$ & $0.6 \pm 0.4$ \\
\hline $\mathrm{dH}_{2} \mathrm{O}$ (control) & 300 & $1.0 \pm 0.5$ & $0.3 \pm 0.3$ & 0 & $0.3 \pm 0.3$ & $0.6 \pm 0.4$ \\
\hline
\end{tabular}

In a comparative analysis of settlements (territories) according to tests on a culture of human lymphocytes, Lenger and Turkestan (comparison territories) has the highest mutagenicity of soil samples, which significantly differs $(\mathrm{p} \leq 0.01)$ from the control (test results for distilled $\mathrm{H} 2 \mathrm{O})$ as well as Kentau $(\mathrm{p} \leq 0.01)$. Since it is not entirely correct to compare the results obtained using distilled water and water extracts of soils, the data on the analysis of a sample of water extracts of soil from the Basshi village, located in the Kerbulak district of the Almaty region in the Altyn-Emel national park (chemically pure territory) is given (IGGC CS MES RK - STP: №BR05236379 «Comprehensive assessment of the impact of nonutilizable and prohibited pesticides on the genetic status and health of the population of Almaty region»). However, no significant differences in the mutagenicity of soil samples taken in different territories and in Basshi village were found. It should be noted that in Turkestan, there is an excess of chromosomal aberrations in comparison with chromatid aberrations. These results indicate the possible presence of not only a chemical, but also a radiation component in the analyzed samples. 
Studies of the sensitivity and correlation between test systems, which are used to analyze the potential hazard of environmental factors, are fundamental for a more accurate assessment of environmental risks, as well as for extrapolating data to other organisms, including humans. The sensitivity of the test systems used is different and depends not only on its resolution. In this regard, one test system detects mutagenic activity in about $40-50 \%$ of the studied factors, while other five test systems allow to detect mutagenic activity in more than $90 \%$ of the studied agents. Therefore, there is no single method that makes it possible to unambiguously assess the genotoxic potential of the test sample, which makes it necessary to use a set of methods performed on different test objects in vitro and in vivo (from microorganisms and higher plants to human and animal cell cultures). In our study we used (for objective reasons) two test systems. For a more complete analysis, it is necessary to continue the studies in dynamics using additional test systems. In this study, both tests used showed a similar level of pollution in villages, according to the chemical analysis of soil and water, despite their different sensitivity. It has mentioned about the importance of correlation between test systems for extrapolating data, for example, to nontarget organisms exposed to pesticides. Therefore, a correlation analysis of the test results was performed.

It should be noted the relationship between the frequency of chromosomal aberrations in the analysis of water samples and water extracts of soils on cultures of human lymphocytes and the frequency of violations in the metaphase of the cell cycle during the Allium-test 0.81 and 0.68 , respectively $(\mathrm{p} \leq 0.01)$. Also, testing water revealed a correlation between the frequency of chromosomal aberrations in cultures of human lymphocytes and the frequency of micronuclei in the interphase during the Allium-test - $0.72(p \leq 0.01)$. This is consistent with literature data showing that cytogenetic abnormalities in Allium cepa cells when testing the degree of genotoxicity of exposure correlate well with cytogenetic abnormalities in mammalian and human cells under similar exposures $[13,14]$. Thus, Rank and Nilsen showed a correlation of $82 \%$ in relation to the carcinogenicity test in rodents and the Allium-test [15].

In a comparative analysis of settlements (territories), the highest mutagenicity of water samples, according to the Allium-test and on the culture of human lymphocytes, is observed in Kentau and its surroundings. It significantly differs $(\mathrm{p} \leq 0.01)$ from the control (test results for distilled $\mathrm{H} 2 \mathrm{O}$ or the comparison area). At the same time, no significant differences in the mutagenicity of water samples taken in individual territories were revealed.

In a comparative analysis of settlements (territories), the highest mutagenicity of water extracts of soil samples, according to tests on a culture of human lymphocytes and Alliumtest, is observed in Lenger and Turkestan (comparison territory). It significantly differs $\left(\mathrm{p} \leq 0.01\right.$ ) from the control (test results for distilled $\mathrm{H}_{2} \mathrm{O}$ ). Perhaps this is due to an overabundance of any compounds, as well as the fact that these tests analyze not the soils themselves, but their water extracts, i.e. substances readily soluble in water contained in the soil. Nevertheless, no significant differences were found in the mutagenicity of the soil samples taken in different territories of Kentau and Basshi and the pure universal soil; the results of testing the soils of the territories of Kentau and its surroundings and the compared territories (Turkestan, Lenger, Orangai village) did not reveal significant differences.

According to the studies on testing water and soil sampled in various territories of Kentau, it is not possible to distinguish a polluted and/or clean area, which indicates general pollution of the surveyed areas with a tendency to increase pollution in some places.

According to the "Criteria for assessing the ecological situation of territories" of the Law of the Republic of Kazakhstan "On social protection of citizens affected by an environmental disaster in the Aral region" - if the level of total mutagenic impacts in water samples and other environmental components is exceeded up to 3 times, the analyzed territory belongs to the zone of ecological emergency. The study of drinking water and soil 
samples has shown a similar situation - the total excess of mutagenic activity in Kentau and its surroundings is increased by 3 times in comparison with the control. There are no significant differences between them and the test results of the compared territories (Turkestan, Orangai village), which allows us to attribute the territories of Kentau to the environmental emergency zone.

\section{References}

1. A.A. Akinova, A.T. Abdreeva, Med. and ecol. Probl. of the Aral Sea reg., 96-97 (1992)

2. Environmental Code of the Republic of Kazakhstan with amendments and additions (02.01.2021)

3. Criteria for assessing the ecological situation of the territories. Approved by the Order of the Minister of Energy of the Republic of Kazakhstan (16 March, 2015, No. 202)

4. A.Levan, Hereditas. 35(1), 325-337 (1949)

5. D.M. Leme, M.A. Marin-Morales, Mutation Research, 682, 71-81 (2009)

6. T.H. Ma, Mutat Res, 426, 103-106 (1999)

7. T.H. Ma, Rev Environ Health, 20(1), 1-14 (2005).

8. Sanitary and epidemiological requirements for water sources, places of water intake for household and drinking purposes, household and drinking water supply and places of cultural and household water use and safety of water bodies. Approved by order of the Minister of National Economy of the Republic of Kazakhstan (16 March, 2015, No. 209)

9. Yu.E. Saet, B.A. Revich, E.P. Yanin, Geochemistry of the environment (Moscow Nedra, 1990)

10. Methodical recommendations for the geochemical assessment of urban areas pollution by chemical elements (IMGCCRE, Moscow,1982)

11. M. Fenech, M. Kirsch-Volders, A. T. Natarajan, J. Surralles, J. W. Crott, J. Parry, H. Norppa, D.A. Eastmond, J.D. Tucker, P. Thomas, Mutagenesis, 26, 125-132 (2011)

12. P.S. Moorhead, P.C. Nowell, W.J. Mellman, D.M. Battips, D.A. Hungerford, Experim. Cell Res, 20, 613-616 (1960)

13. A. Barberrio, J. C. Voltolini, M. L.S. Mello, Ecotoxicol., 20, 927-935 (2011)

14. G. Fiskesjo, Hereditas, 102, 99-112(1985)

15. J. Rank, M.H. Nielsen, Mutat. Res., 312, 17-24(1994) 